Original Article

\title{
Quality of life aspects of patients with HIV/tuberculosis co-infection*
}

\author{
Aspectos da qualidade de vida de pacientes com coinfecção HIV/ tuberculose \\ Aspectos de la calidad de vida de pacientes con coinfección vih/tuberculosis
}

\section{Larissa de Araújo Lemos ${ }^{1}$, Alexsandra Rodrigues Feijão ${ }^{2}$, Elucir Gir ${ }^{3}$, Marli Teresinha Gimeniz Galvão ${ }^{4}$}

\begin{abstract}
Aim: To investigate the quality of life of patients with HIV and tuberculosis co-infection and grasping the changes imposed in order to live with both transmissible diseases simultaneously. Methods: Qualitative-quantitative research, undertaken at a specialized outpatient clinic in Fortaleza, Brazil, between 2009 and 2010, involving 34 co-infected patients. For data collection, a quality of life scale called HAT-QoL was used, which consists of 42 items, as well as open questions to perceive the changes the disease causes. Results: Most participants suffered from pulmonary tuberculosis, were male and their education level was low. Quality of life was impaired in those domains related to economic, sexual and secrecy issues. It was also evidenced that the co-infection imposes changes in daily life that underline and further harm quality of life. Conclusion: Experiencing co-infection, despite appropriate treatment, causes changes in the patients' lives, whose repercussions can be mitigated through health-promoting interventions.
\end{abstract}

\section{RESUMO}

Objetivo: Investigar a qualidade de vida de pacientes com coinfecção HIV/ tuberculose e apreender as mudanças impostas para viver simultaneamente com estas doenças transmissíveis. Métodos: Pesquisa com abordagem qualiquantitativa, realizada em ambulatório especializado em Fortaleza, Brasil, entre 2009 e 2010, com 34 coinfectados. Para coleta de dados foi utilizada uma escala de qualidade de vida, denominada HAT-QoL que possui 42 itens e questões abertas para possibilitar perceber as mudanças em face das doenças. Resultados: A maioria dos participantes tinha tuberculose na forma pulmonar, eram homens, com pouca escolaridade. A qualidade de vida mostrou-se prejudicada nos domínios relacionados às questões econômicas, sexuais e de sigilo. Ainda, foi evidenciado, que a coinfecção impõe mudanças no cotidiano que corroboram e ampliam o comprometimento da qualidade de vida. Conclusão: Vivenciar a coinfecção, mesmo com terapêutica adequada, produz alterações na vida dos infectados, cujas repercussões podem ser amenizadas com intervenções que promovam a saúde.

Descritores: HIV; Tuberculose; Qualidade de vida

\section{RESUMEN}

Objetivo: Investigar la calidad de vida de pacientes con coinfección VIH/ tuberculosis y aprender los cambios impuestos para vivir simultáneamente con estas enfermedades transmisibles. Métodos: Investigación con abordaje cualicuantitativo, realizado en consultorio externo especializado en Fortaleza, Brasil, entre 2009 y 2010, con 34 coinfectados. Para la recolección de datos fue utilizada una escala de calidad de vida, denominada HAT-QoL que posee 42 items y preguntas abiertas para posibilitar la percepción de los cambios frente a las enfermedades. Resultados: La mayoría de los participantes tenía tuberculosis pulmonar, eran hombres, con poca escolaridad. La calidad de vida se mostró perjudicada en los dominios relacionados a las preguntas económicas, sexuales y de sigilo. Aun, fue evidenciado, que la coinfección impone cambios en el cotidiano que corroboran y amplían el compromiso d ela calidad de vida. Conclusión: Vivenciar la coinfección, inclusive con terapéutica adecuada, produce alteraciones en la vida de los infectados, cuyas repercusiones pueden ser amenizadas con intervenciones que promueban la salud.

Descriptores: VIH; Tuberculosis; Calidad de vida

\footnotetext{
* Research developed at Hospital São José de Doenças Infecciosas - HSJ - Fortaleza - (CE), Braz̨il.

${ }^{1}$ Graduate student (Master's), Graduate Nursing Program, Universidade Federal do Ceará-UFC - Fortaleza (CE), Brazil.

${ }^{2}$ Ph.D. in Nursing, Associate Professor, Universidade Federal do Rio Grande do Norte - UFRN, Brazil.

${ }^{3}$ Ph.D. in Nursing. Professor, University of São Paulo at Ribeirão Preto College of Nursing - USP - São Paulo (SP), Brażil.

${ }^{4}$ Ph.D. in Tropical Illnesses. Associate Professor, Universidade Federal do Ceará - UFC - Fortaleza (CE), Brazil.
} 


\section{INTRODUCTION}

Around the world, approximately 33 million people have been infected by HIV and 2.2 billion by Mycobacterium tuberculosis. A study about tuberculosis (TB) affirms that this disease remains an important cause of morbidity and mortality and suffering among HIV patients and their relatives. Hence, co-infection can strongly affect the epidemic evolution of both conditions, representing a challenge to public health ${ }^{(1)}$.

Every year, the number of new cases in Brazil is estimated at 110 thousand. Therefore, the country stands out because of the highest incidence rate in Latin America and ranks among the 16 countries with most TB cases around the world ${ }^{(2)}$.

Around the globe, HIV infection has modified the epidemiological trend of TB in the poorest regions. The global prevalence of HIV entails implications for TB control, mainly in countries with high disease indices ${ }^{(1,3)}$.

The advance of antiretroviral therapy against AIDS permits increasing the life expectancy of HIV patients and improving their quality of life ${ }^{(4,5)}$. It should be highlighted that the quality of life of patients infected by the virus is not just related to the possibility of a longer life, as contact with HIV exposes patients to situations of discrimination, abandonment, segregation, stigmatization, lack of social and financial resources, ruptures in affective relations and sexual changes ${ }^{(5)}$.

Interest in quality of life assessment also includes tuberculosis patients as, although it is a curable disease, the duration of treatment and the number of medicines taken can compromise these patients' quality of $\operatorname{life}^{(6)}$.

The World Health Organization defines the term quality of life as "individuals' perception of their position in life in the context of the culture and value systems in which they live and in relation to their goals, expectations, standards and concerns" ${ }^{\text {(7) }}$.

In that sense, quality of life comprises different aspects of individuals' life, including physical, mental and social aspects. Hence, the improvement in subjective wellbeing, feeling of vitality and better affective and social bonds should be considered ${ }^{(8)}$. Thus, the term quality of life has been used as a synonym of health condition, functional status, psychological wellbeing, satisfaction with life and one's needs and assessment of one's own life ${ }^{(5)}$.

The aim was to investigate the quality of life of patients with HIV/TB co-infection and grasp the changes imposed to live with both transmissible diseases at the same time.

\section{METHODS}

This cross-sectional and exploratory research with a qualitative-quantitative approach was undertaken at the specialized outpatient clinic of Hospital São José de Doenças Infecciosas (HSJ) in Fortaleza, Ceará, Brazil.

The number of patients was obtained based on the total number of notifications of $\mathrm{HIV} / \mathrm{TB}$ co-infection at HSJ, where 136 cases of co-infected patients were notified in 2009. Twenty-nine of these patients abandoned treatment (abandonment rate $=21.3$ ) and 37 died (death rate $=27.2$ ), so that 70 co-infected patients were followed. An intentional sample of 34 co-infected patients was obtained, which corresponded to $48 \%$ of all patients monitored $(n=70)$. During data collection, four patients refused to participate.

Participants were recruited through convenience sampling, that is, as they attended the service for health care, during six months, between November 2009 and April 2010.

In this study, the following inclusion criteria were adopted: individuals aged 18 years or older, male and female, HIV-positive and diagnosed with tuberculosis, in physical and cognitive conditions to answer the interview.

Data were collected through private interviews, using a semi-structured instrument with the following variables: sociodemographic, epidemiological, clinical data and open questions, with a view to grasping the changes imposed to simultaneously live with HIV and TB.

To investigate the patients' quality of life, the scale called HIV/AIDS - Quality of Life (HAT-QoL) was adopted, a specific instrument to assess the quality of life of HIV-positive individuals, originally written in English ${ }^{(9)}$ and validated in Brazil ${ }^{(5)}$. The scale consists of 42 items, divided in nine domains, which are: general activities, sexual activities, concern with keeping the infection secret, concern with health, financial concern, awareness about HIV, satisfaction with life, medication issues and trust in the professional. For each item, five alternative answers are available, ranging from 1 to 5 . The total score ranges from 42 to 210.

For analysis purposes, the added score in each domain was transformed into a weighted index, on an analogue scale from 0 to 100 , in which zero corresponds to the worst quality of life and scores close to 100 to the best, considering scores below 75 as impaired quality of life.

Data were analyzed using Statistical Package for Social Sciences software - (SPSS 15.1) and sociodemo- 
graphic and clinical variables were treated with the help of relative frequencies, means and medians. To describe the domain scores on the HAT-QoL, means, standard deviations and percentiles were used. In addition, the Kolmogorov-Smirnov Test was adopted for normality analysis. For the correlations between the domain scores, Pearson's linear correlation coefficient $r$ were applied to variables with normal distribution. Correlations with $\mathrm{p}<0.05$ were considered statistically significant.

To analyze the open questions, content analysis recommendations were followed, involving three steps: 1)- grouping statements; 2)- exploring testimonies, with a view to combining and numbering the statements and obtaining thematic categories; and treating and categorizing the results, associating similar contents. Two categories were constructed: Impact on quality of life and Lifestyle changes.

In compliance with requirements, approval was obtained from the Institutional Review Board, under Protocol 035/2009. Subjects were informed about the study and their participation was formalized by signing the Informed Consent Form.

\section{RESULTS}

In this research, 34 patients with $\mathrm{HIV} / \mathrm{TB}$ co-infection participated, mostly male $(88.2 \%)$, between 18 and 29 years old and between 6 and 11 years of education $(70.6 \%)$. As regards the marital status, $58.8 \%$ were single. What employment is concerned, $35.3 \%$ were unemployed and $61.8 \%$ gained a family income of between one and two minimum wages. Most patients had been diagnosed with HIV less than one year earlier $(58.8 \%)$. Concerning the clinical form of TB, $64.7 \%$ suffered from pulmonary tuberculosis. A history of opportunistic diseases was identified in $32.4 \%$ of the patients, including tumors, syphilis, herpes zoster, neurotoxoplasmosis, pneumocystosis, hepatites and pneumonia (Table 1).

Data in Table 2 show the descriptive values and descriptive level (p) of the normality test applied to the HAT-QoL domain scores. To analyze the domain trust in the professional, with a mean score of 78.4 in this research, the choice was made to analyze the physician, as this was the professional involved in most outpatient consultations. This domain indicated no impairment for the co-infected patients quality of life.
Table 1. Distribution of sociodemographic variables of patients co-infected with HIV/TB. Fortaleza, 2010

\begin{tabular}{lc}
\hline Variables & $\begin{array}{c}\text { Patients } \\
\mathbf{n}(\%)\end{array}$ \\
\hline $\begin{array}{l}\text { Gender } \\
\text { Male }\end{array}$ & $30(11.8)$ \\
Female & $4(88.2)$ \\
Age (years) & \\
$\leq 29$ & $13(38.2)$ \\
$30-39$ & $12(35.3)$ \\
$\geq 40$ & $9(26.5)$ \\
Education (years of study) & \\
$0-5$ & $10(29.4)$ \\
$6-11$ & $24(70.6)$
\end{tabular}

\section{Marital status}

Married/living together $9(26.5)$

Single 20(58.8)

Separated/widowed 5(14.7)

Monthly income (minimum wage)

$\begin{array}{lc}\text { No income } & 6(17.6) \\ 1-2 & 21(61.8) \\ \geq 3 & 7(20.6)\end{array}$

Occupation

Employed 10(29.4)

Unemployed/retired 24(70.6)

Diagnosis time of HIV infection (years)

$\leq 1 \quad 20(58.8)$

$2-5 \quad 5(14.7)$

$6-9 \quad 9(26.5)$

Clinical form of tuberculosis

$\begin{array}{ll}\text { Pulmonary 22(64.7) } & \text { 22 }\end{array}$

Extrapulmonary 10(29.4)

Mixed 2(5.9)

Opportunistic diseases

Yes $11(32.35)$

No 23(67.65) 
Table 2. Distribution of descriptive values and descriptive level (p) of normality test applied to HAT-QoL domain scores among patients co-infected with HIV/TB. Fortaleza, 2010

\begin{tabular}{lcccccccc}
\hline Domains & Mean & SD & Minimum & p25 & Median & p75 & Maximum P-value \\
\hline General activities & 56.5 & 18.6 & 25.0 & 39.3 & 57.1 & 71.4 & 89.3 & 0.858 \\
Sexual activity & 52.5 & 19.4 & 0.0 & 41.7 & 50.0 & 66.7 & 83.3 & 0.813 \\
Concern with secrecy & 36.0 & 28.4 & 0.0 & 10.0 & 30.0 & 55.0 & 100.0 & 0.492 \\
Concern with health & 56.7 & 21.3 & 10.0 & 40.0 & 55.0 & 70.0 & 100.0 & 0.731 \\
Financial concern & 41.7 & 25.6 & 0.0 & 23.5 & 40.6 & 59.4 & 93.8 & 0.616 \\
Awareness about HIV & 72.0 & 27.5 & 16.7 & 47.9 & 83.3 & 100.0 & 100.0 & 0.119 \\
Satisfaction with life & 58.8 & 19.3 & 3.1 & 46.9 & 62.5 & 75.0 & 84.4 & 0.623 \\
Medication issues & 73.0 & 14.0 & 31.3 & 67.2 & 75.0 & 81.3 & 93.8 & 0.683 \\
Trust in professional & 78.4 & 21.4 & 0.0 & 66.7 & 83.4 & 91.7 & 100.0 & 0.256 \\
\hline
\end{tabular}

$\mathrm{SD}=$ standard deviation; $\mathrm{p} 25=$ percentile $25 ; \mathrm{p} 75=$ percentile 75.

In the analysis of the correlations between the HAT-QoL domains, the general activity domain was correlated with financial concern, satisfaction with life and trust in the professional (Table 3). According to the correlation between the former two, concern with compliance with routine activities is closely linked with the inability to work and with the economic situation. It should also be highlighted that the correlation among these two domains, trust in the professional and satisfaction with life is easy to understand, as health professionals' support is partially responsible to encourage patients' establishment and maintenance of self-care.

Table 3. Distribution of correlations between HAT-QoL domains among patients co-infected with HIV/TB. Fortaleza, 2010

\begin{tabular}{|c|c|c|c|c|c|c|c|c|c|}
\hline Scores & $\begin{array}{l}\text { General } \\
\text { activities }\end{array}$ & $\begin{array}{l}\text { Sexual } \\
\text { activity }\end{array}$ & $\begin{array}{c}\text { Concern } \\
\text { with secrecy }\end{array}$ & $\begin{array}{l}\text { Concern } \\
\text { with health }\end{array}$ & $\begin{array}{c}\text { Financial } \\
\text { concern }\end{array}$ & $\begin{array}{l}\text { Awareness } \\
\text { about HIV }\end{array}$ & $\begin{array}{l}\text { Satisfaction } \\
\text { with life }\end{array}$ & $\begin{array}{l}\text { Medication } \\
\text { issues }\end{array}$ & $\begin{array}{l}\text { Trust in } \\
\text { professional }\end{array}$ \\
\hline General activities & 1.0000 & 0.158 & 0.909 & 0.166 & 0.034 & 0.100 & 0.000 & 0.144 & 0.014 \\
\hline Sexual activity & - & 1.0000 & 0.739 & 0.120 & 0.417 & 0.633 & 0.016 & 0.020 & 0.884 \\
\hline $\begin{array}{l}\text { Concern with } \\
\text { secrecy }\end{array}$ & - & - & 1.0000 & 0.016 & 0.718 & 0.039 & 0.686 & 0.012 & 0.745 \\
\hline $\begin{array}{l}\text { Concern with } \\
\text { health }\end{array}$ & - & - & - & 1.0000 & 0.037 & 0.008 & 0.153 & 0.648 & 0.487 \\
\hline $\begin{array}{l}\text { Financial } \\
\text { concern }\end{array}$ & - & - & - & - & 1.0000 & 0.200 & 0.477 & 0.990 & 0.587 \\
\hline $\begin{array}{l}\text { Awareness about } \\
\text { HIV }\end{array}$ & - & - & - & - & - & 1.0000 & 0.045 & 0.826 & 0.060 \\
\hline $\begin{array}{l}\text { Satisfaction with } \\
\text { life }\end{array}$ & - & - & - & - & - & - & 1.0000 & 0.032 & 0.001 \\
\hline $\begin{array}{l}\text { Medication } \\
\text { issues }\end{array}$ & - & - & - & - & - & - & - & 1.0000 & 0.002 \\
\hline $\begin{array}{l}\text { Trust in } \\
\text { professional }\end{array}$ & - & - & - & - & - & - & - & - & 1.0000 \\
\hline
\end{tabular}


In addition, as observed, sexual activity was correlated with satisfaction with life and medication issues (Table 3). This correlation is justified by the fact that AIDS imposes changes in sexual relationships, considering that most study subjects were sexually contaminated.

The domain concern with keeping the infection a secret was correlated with health concerns and awareness about HIV (Table 3). An inversely proportional correlation was found between concern with keeping the infection a secret and the medication issues domain. Hence, this result demonstrated that the imposed secrecy furthers infected patients' difficulty to accept the diagnosis. Therefore, this situation can hamper medication adherence.

In this case, the correlation among concern with health, financial concern and awareness about HIV (Table 3) suggests that accepting the diagnosis can make it easier to live with the disease, and that financial issues are intrinsic in the maintenance of healthy living habits.

Also, a correlation was observed between awareness about HIV and satisfaction with life (Table 3). In view of this result, when patients gain awareness about their disease and start to accept and cope with it, they demonstrate greater satisfaction with life when compared to patients who do not accept the diagnosis.

To illustrate the different changes in the co-infected patients quality of life, the testimonies taken from the open questions underline patients' difficulties to live with HIV and TB, in accordance with the categories presented next.

\section{Impact on quality of life}

Patients act differently when confronted with the co-infection diagnosis, ranging from indifference to despair. In this context, the desire to die or even the idea of suicide is sometimes part of the feelings experienced after a positive serum status, mainly when the co-infection diagnosis is discovered simultaneously. The testimonies revealed these contradictions:

"Sometimes I get concerned, I have some fits, but I know that it's psychological, I get sort of depressed, I have a feverish feeling, but I don't have a fever really".

"I got depressed, but I'm better now, sometimes I cry, I'm concerned with my children. I'm very scared of what might happen to me because of the HIV".

After the initial impact of the discovery, however, the negative feelings often disappear, mainly when patients receive support from health professionals, and particularly from relatives and friends. The following testimonies picture that situation:

'It's not because I've got this disease that I'm gonna get sad. I lead a normal life, but at first I got depressed".

"I got sad at first [discovery of the diagnosis], but then I got over it and I even got a partner, we're together until now, that helps me a lot".
Despite the shock when they discover that they are HIV-positive, some patients reported indifference to the diagnosis, especially in those cases when they were already suspecting the infection. Sometimes, patients have no idea about the severity of the disease, mainly due to low education levels, so that some patients' primary concerns are due to possible economic difficulties and probable consequences for treatment. This reaction may indicate a flight from reality or denial of the disease, that is, a way of disguising or even hiding their feelings.

"I think that my life is excellent, despite the co-infection".

"I live well, financially and healthily, the diseases haven't influenced anything".

\section{Lifestyle changes}

Most participants revealed that different changes took place in their living habits. The discovery of and contact with the co-infection diagnosis generate new behaviors and feelings towards life, as demonstrated in the following testimonies:

"[...] I don't go out as much as I used to, I have reduced contact with my friends".

"I have left aside my social life, taken distance from friends, I have stopped going out, my social life has changed a lot, I think that, by taking distance from people I protect myself against prejudice".

The main lifestyle changes in view of the diagnosis relate to the reduction of risk behaviors, as well as the decrease or cessation of nighttime leisure, which most participants find inappropriate for people in disease situations. The following testimony illustrates that assertion:

"I have quit drinking and smoking, I go out less. I have quit my job, as I feel tired and inapt to work.".

Another significant change in daily activities is the intake of different drugs (antiretroviral and antituberculostatic agents), which by themselves can entail different collateral effects, compromising these individuals' quality of life, as demonstrated in the following testimonies:

"I feel very bad when I take the drugs, there are different ones and the collateral effects are horrible, I've even talked to the physician to change the medicines."

"When I started taking the drugs I had to stop working, because I got sick. I stopped going out because of the drugs, I'm afraid of the prejudice."

As revealed in this study, despite the discovery about the co-infection, the diagnosis that most affected and changed patients' living habits was the discovery of the HIV. Therefore, the need for psychological accompaniment is emphasized, with a view to emotional and mental wellbeing, as follows:

"Tuberculosis is bad because you feel down, lose weight and your appetite, but after you start taking the medicines things get better. The worse is that virus [referring to HIV] really, 'cause there's no cure."

"I don't feel well after I have discovered the diagnosis. I think. I've got the panic syndrome". 


\section{DISCUSSION}

In this study, male patients were predominant, in line with studies that indicate higher $\mathrm{HIV} / \mathrm{TB}$ co-infection rates among men ${ }^{(11-13)}$. A combination of biological and social factors can be responsible for this different between men and women, mainly deriving from physiological, behavioral and cultural distinctions.

The predominant age range of co-infection cases, then, followed the same patterns as in several other studies, which also revealed the predominance of young adults, including a significant from of the economically active population ${ }^{(12-14)}$. The high frequency of co-infection in young adults may be related to the adopted lifestyle, as they may be more exposed to Mycobacterium tuberculosis and $\mathrm{HIV}^{(14)}$.

In this study, the analysis of aspects related to the patients' health condition indicates the need for detailed attention, as HIV infection can be considered one of the main risk factors for the development of active $\mathrm{TB}$, based on a latent infection ${ }^{(12-15)}$. On the opposite, TB can accelerate the course of the HIV infection and the diagnosis frequently becomes difficult. In addition, the HIV infection changes the TB infection, its clinical symptoms, treatment duration and tolerance of tuberculostatic agents $^{(1,16)}$.

Also according to the literature, patients co-infected with HIV/TB obtain lower quality of life scores when compared to HIV patients with TB. Hence, the occurrence of two stigmatizing diseases can reduce patients' quality of life and affect their physical, social and psychological well-being ${ }^{(17)}$. Other authors appoint the need for special attention to the quality of life of HIV patients, as this condition can entail countless biopsychosocial consequences that influence these people's quality of life ${ }^{(4-18)}$.

It should be highlighted that antiretroviral therapy reduces the emergence of opportunistic infections and their symptoms, but does not exempt patients from death threat, disease stigma and medication side effects. Therefore, at the same time as these people's survival is expanded, it is increasingly relevant for health professionals to know about and furthers these clients' quality of life. This evaluation permits comparing the global impact of the disease and of different treatments on the patient's well-being as a whole ${ }^{(8)}$.

When people discover their disease, they experience sexuality-related conflicts. Thus, AIDS imposes changes in sexual activities, considering that patients' conditions due to the disease cause an aversion against sexual relationships. Hence, despite sexual desire, they avoid relationships ${ }^{(19)}$.

Even after discovering the diagnosis, most seropositive individuals omit it as long as possible, in the attempt to avoid a possible social isolation if they declared their positive status. Also, the experiences the patients reported are underlined by another studies, in which it was verified that, in case of HIV, patients feel obliged to maintain secrecy to avoid losing their job, as they frequently need to be absent for health monitoring and periodical tests ${ }^{(20)}$.

In general, health concerns are a desirable attitude that is expected from anyone, especially HIV patients. When excessive, however, these may hamper their quality of life. Therefore, orientations and care need to be intensified with a view to avoiding too much health concerns. This finding is in accordance with research in which similar negative effects on quality of life were found, due to the burden of health concerns in patients' lives ${ }^{(4,5)}$.

In that sense, many reasons trigger patients' health concerns, among which economic, social and cultural factors are highlighted, as well as knowledge levels and the ability to understand the disease and treatment ${ }^{(21)}$. In this study, it was found that low income and education influence the living conditions of individuals co-infected with HIV/TB.

Quality of life, social relations and leisure activities are considered important, mainly for HIV-positive patients to continue treatment. In these cases, a strong relation exists between non-adherence and the presence of depression and unsatisfactory social support. In view of co-infection with TB, HIV patients further need social support. This information implies the systemized observation of medication intake; the existence of depression symptoms, including lack of interest; and the inclusion of people in patients' health monitoring ${ }^{(22)}$.

Concerning the initial fear after discovering the infection, this may be explained by the fact that both AIDS and its treatment remain hardly known to the general population, despite constant media campaigns. In this context, incomplete, misleading and contradictory information disseminated in communication means can provoke comprehension difficulties about the disease's progression ${ }^{(23)}$.

\section{CONCLUSION}

In this study, negative effects could be identified in the quality of life domains related to financial concerns, sexual activities and concern with secrecy about the infection. Correlations were found among different domains, suggesting that quality of life results from a combination of biopsychosocial factors.

Other aspects impairing the quality of life of patients co-infected with HIV/TB relate to economic issues, fear of disseminating the diseases, concern with one's own health and with sexuality. Also, to live with 
the co-infection, daily life is affected, manifested by fear and sadness. As identified, changes in living habits, like the reduction of habits that are harmful to health, were adopted to cope with these diseases.

In this perspective, this study is aimed at contributing to improvements in the quality of life of people living with co-infection, as well as at supporting health pro-

\section{REFERENCES}

1. Granich R, Akolo C, Gunneberg C, Getahun H, Williams P, Williams B. Prevention of tuberculosis in people living with HIV. Clin Infec Dis. 2010; 50 Suppl 3:S215-22.

2. Brasil. Ministério da Saúde. Secretaria de Vigilância em Saúde. Programa Nacional de Controle da Tuberculose. Manual de recomendações para o controle da tuberculose no Brasil. Brasília (DF): Ministério da Saúde; 2010.

3. Jamal LF, Moherdaui F. Tuberculose e infecção pelo HIV no Brasil: magnitude do problema e estratégias para o controle. Rev Saúde Pública. 2007; 41Suppl 1:104-10.

4. Reis RK, Haas VJ, Santos CB, Teles SA, Galvão MT, Gir E. Symptoms of depression and quality of life of people living with HIV/AIDS. Rev Latinoam Enferm. 2011;19(4):874-81.

5. Galvão MT, Cerqueira AT, Marcondes-Machado J. [Evaluation of quality of life among women with HIV/AIDS using HATQoL]. Cad Saúde Pública. 2004; 20(2):430-7. Portuguese.

6. Guo N, Marra F, Marra CA. Measuring health-related quality of life in tuberculosis: a systematic review. Health Qual Life Outcomes. 2009; 7:14.

7. World Health Organization. Country protocol for developing the WHO quality of life (WHOQOL): HIV/aids module. Genebra: WHO; 1997.

8. Geocze L, Mucci S, De Marco MA, Nogueira-Martins LA, Citero V de A. Quality of life and adherence to HAART in HIV-infected patients. Rev Saúde Pública. 2010: 44(4):743-9.

9. Holmes WC, Shea JA. A new HIV/AIDS-targeted quality of life (HAT-QoL) instrument: development, reliability, and validity. Med Care. 1998; 36(2):138-54 .

10. Bardin L. Análise de conteúdo. Lisboa: Edições 70; 2009.

11. Carvalho BM, Monteiro AJ, Pires Neto RJ, Grangeiro TB, Frota CC. Factors related to HIV/tuberculosis coinfection in a Brazilian reference hospital. Braz J Infect Dis. 2008;12(4):281-6.

12. Zenteno-Cuevas R, Montes-Villaseñor E, Morales-Romero J, Del Campo GC, Cuevas B. Co-infection and risk factors of tuberculosis in a Mexican HIV+ population. Rev Soc Bras Med Trop. 2011;44(3):282-5.

13. Cheade MF, Ivo ML, Siqueira PH, Sá RG, Honer MR. [Characterization of tuberculosis among HIV/AIDS patients fessionals to establish interventions that can promote the control of the HIV infection and the cure of TB.

\section{ACKNOWLEDGEMENTS}

Funding for the study this paper derived from was obtained from the Brazilian Scientific and Technological Development Council (CNPq), Process 479237/2010-7.

at a referral center in Mato Grosso do Sul]. Rev Soc Bras Med Trop. 2009; 42(2):119-25. Portuguese.

14. Rodrigues JL, Fiegenbaum M, Martins AF. [Prevalence of tuberculosis/HIV coinfection in patients from Model Health Centre in Porto Alegre, Rio Grande do Sul]. Sci Med. 2010; 20(3):212-7.Portuguese.

15. Perkins MD, Cunningham J. Facing the crisis: improving the diagnosis of tuberculosis in the HIV era. J Infec Dis. 2007; 196 Suppl 1:S15-27.

16. Santos JS, Beck ST. A coinfecção tuberculose e HIV: um importante desafio - Artigo de revisão. Rev Bras Anal Clin. 2009; 41(3):209-15.

17. Deribew A, Tesfaye M, Hailmichael Y, Negussu N, Daba S, Wogi A et al. Tuberculosis and HIV co-infection: its impact on quality of life. Health Qual Life Outcomes [Internet]. 2009 [cited 2010 Jun 24]; 7: [about 10 p.]. Available from: http://www.ncbi.nlm. nih.gov/pmc/articles/PMC2809048/pdf/1477-7525-7-105.pdf

18. Gaspar J, Reis RK, Pereira FM, Neves LA, Castrighini CC, Gir E. Quality of life in women with HIV/AIDS in a municipality in the state of São Paulo. Rev Esc Enferm USP. 2011; 45(1):225-31.

19. Castanha AR, Coutinho MP, Saldanha AA, Ribeiro CG. [Life quality evaluation in HIV serum-positive individuals]. Estud Psicol (Campinas). 2007; 24(1):23-31. Portuguese.

20. Carvalho CM, Galvão MT, Silva RM. Life changes among women with the adquired inmune deficiency syndrome. Acta Paul Enferm. 2010; 23(1):94-100.

21. Feijão AR, Lopes MV, Galvão MT. Importance of the Supportive-educative System of Orem Model in the patient compliance-reflexive study. Online Braz J Nurs [Internet]. 2009 [cited 2010 Jun 24]; 8(2): [about9 p.]. Available from: http:// www.objnursing.uff.br//index.php/nursing/article/view/2213

22. Neves LA, Reis RK, Gir E. [Compliance with the treatment by patients with the co-infection HIV/Tuberculosis: integrative literature review]. Rev Esc Enferm USP. 2010; 44(4):1129-34.

23. Cardoso AL, Marcon SS, Waidmani MA. [The impact of discovering HIV-positive status on people with HIV/AIDS and their families]. Rev Enferm UERJ. 2008; 16(3):326-32. Portuguese. 